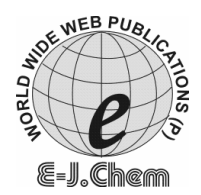

http://www.e-journals.net
ISSN: 0973-4945; CODEN ECJHAO

E-Journal of Chemistry

Vol. 5, No.4, pp. 810-813, October 2008

\title{
Vermicomposting of Vegetable Wastes Using Cow Dung
}

\author{
K. MUTHUKUMARAVEL, A. AMSATH* ${ }^{*}$ and M. SUKUMARAN" \\ P. G. and Research Department of Zoology, \\ Khadir Mohideen College, \\ Adirampattinam-614 701, Tamil Nadu, India. \\ \#Department of Ancient Sciences, \\ Tamil University, \\ Thanjavur-613 005, Tamil Nadu, India. \\ aamsath@gmail.com
}

Received 29 April 2008; Accepted 14 June 2008

\begin{abstract}
Municipal solid wastes are mainly from domestic and commercial areas containing recyclable toxic substances, compostable organic matter and others. With rapid increase in population, the generation of municipal solid wastes has increased several folds during last few years. Disposal of solid wastes can be done by methods like land filling, incineration, recycling, conversion into biogas, disposal into sea and composting. Vermicomposting is one of the recycling technologies which will improve the quality of the products. The present study aims to find out the possibility of utilization of vegetable wastes for vermiculture. Earthworm Megascolex mauritii cultured in plastic trays $(45 \times 30 \times 30 \mathrm{~cm})$ containing soil alone (control) $(\mathrm{T} 1)$, soil + cow dung (T2), soil + vegetable waste (T3) and soil + vegetable waste + cow dung (T4) for 60 days. Nutrient values were determined from the compost and compared with that of the control. From these results, it was found that NPK values were maximum in compost obtained from vegetable waste with the use of cow dung.
\end{abstract}

Keywords: Earthworm, Vegetable wastes, Cow dung, NPK.

\section{Introduction}

Earthworms are often referred to as farmer's friends and natures polughmente ${ }^{1}$. Earthworms are extremely important in soil formation, principally through their activities in consuming organic matter, fragmenting and mixing it intimately with mineral particles to form aggregates. During their feeding, earthworms promote microbial activity greatly, which inurn accelerates the breakdown of organic matter and stabilization of soil aggregates ${ }^{2}$. 
Disposal of solid wastes can be done by many methods, like land filling, incineration, recycling, conversion to biogas, disposal in to sea and composting. Composting is biological decomposition and stabilization of organic material by microbial action.

Vermicompostion is one of the recycling technologies which will improve the quality of products $^{3-8}$. The present study was undertaken to convert vegetable waste into value added vermicompost.

\section{Experimental}

Earthworms, Megascolex mauritii were collected from plantain farms in and around Pattukkottai. The vegetable wastes were collected from Pattukkottai Market. The vermin sheds were prepared using plastic trays $(45 \times 30 \times 30 \mathrm{~cm})$ containing soil (control, T1), soil + cow dung (T2), soil + vegetable waste (T3) and soil + vegetable waste + cow dung (T4) with replicates for 60 days. Ten earthworms were introduced into each tray. The bedding was kept moist through out the experiment by regular watering. The experiment was terminated on the 60th day and the vermicompost produced by the earthworms was harvested for analysis. The parameters such as $\mathrm{pH}^{9}$, the nutrients such as total nitrogen, phosphorus and potassium ${ }^{10}$ were analyzed.

\section{Results and Discussion}

The nutrient values of vermicompost obtained in this study are presented in Table 1 and Figure 1. The pH of soil (control, T1) value was 7.5. The $\mathrm{pH}$ of $\mathrm{T} 4$ compost showed significant variation when compared to the others. The overall increase of $\mathrm{pH}$ may be attributed to the decomposition of nitrogenous substrates resulting in the production of ammonia. Ammonia which forms a large proportion of the nitrogenous matter was excreted by earthworms ${ }^{11}$. Casts may cause a temporary rise in soil $\mathrm{pH}^{7}$ From the results, it was clear that there was s significant increase in the NPK content in the vermicompost. The present study supports the work of Lee ${ }^{12}$ who found that the earthworm casts contain more nitrogen, phosphorous and calcium. Esther Rani ${ }^{13}$ found that the worm Eisenia fetida is capable of ingesting and excreting orgnic materials at a high rate. Gunathilagaraj and Ravignanam ${ }^{14}$ reported that the macro and micronutrients in the vermicompost of semicultural wastes were more. Gaur ${ }^{15}$ found that the nutrients are richer in the earthworm casts. Lakshmi Bai and Vijayalakshmi ${ }^{16}$ have reported similar increase in NPK values on subjecting sugar factory filter press mud to vermicomposting. Umamaheswari and Vijayalakhsmi ${ }^{7}$ found that macronutrients NPK and micronutrients $\mathrm{Ca}$ and $\mathrm{Fe}$ were more. Ravichandran et $a l^{6}$ observed more NPK in the compost than that in the initial soil. The NPK content of the vermicompost prepared from vegetable waste and cowdung has also shown a maximum increase when compared with the compost prepared using individual constituents. The cow dung influenced the rate of vermicomposition and increased the amount of macronutrients in the vermicompost ${ }^{17,18}$. The increased nitrogen may be due to nitrogenous metabolic products of earthworms which are returned to the soil through casts, urine, muco-proteins and earthworm tissue ${ }^{7}$. Hence, it is clear that the mixture of vegetable waste and cow dung is suitable for the production of higher quality vermicompost when compared with the subjecting the same components individually. 
Table 1. Nutrient values of vermicompost (values are given in percentage).

\begin{tabular}{lllll}
\hline Treatment & $\mathrm{pH}$ & $\mathrm{N}$ & $\mathrm{P}$ & $\mathrm{K}$ \\
\hline Soil + Earthworm (T1) & 7.5 & 1.45 & 0.57 & 1.98 \\
Soil + Earthworm + Cow dung (T2) & 7.9 & 1.62 & 1.20 & 2.65 \\
Soil + Earthworm + Vegetable waste (T3) & 8.0 & 1.50 & 1.10 & 3.26 \\
Soil + Earthworm + Cow dung + Vegetable waste (T4) & 8.3 & 1.76 & 1.60 & 4.98 \\
\hline
\end{tabular}

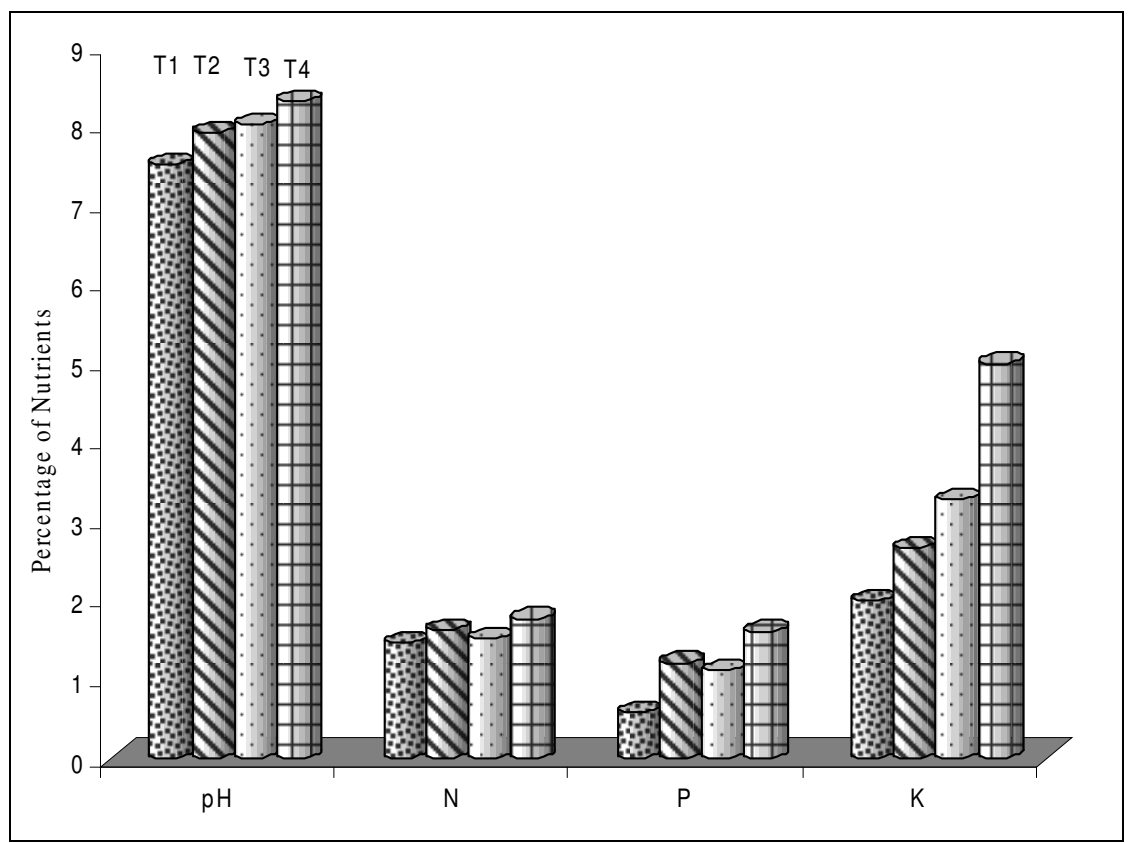

Figure 1. Comparison of the nutrients in the different treatments of vermicompost.

\section{Acknowledgement}

The authors are grateful to the Secretary and Principal, Khadir Mohideen College, Adirampattinam-614 701, Tamil Nadu, India and Assistant Soil Chemist, Soil Testing Laboratory, Tiruchirappalli - 620 020, Tamil Nadu, India for providing the necessary facilities to analyze the $\mathrm{pH}, \mathrm{N}, \mathrm{P}$ and $\mathrm{K}$ of soil.

\section{References}

1. Darwin C R, The formation of vegetable mould through the action of worms with observations on their habits. Murray London, 1881, 298-299.

2. $\quad$ Dindal, D L, Quest Entomol., 1985, 12, 587-594.

3. Bhawalkar, U S, Vermiculture biotechnology for LEISA, Seminar on Low External input sustainable agriculture, Amsterdam, Netherlands, 1991.

4. Jayasankar S, Studies on vermicomposting as a method of sewage sludge disposal, M. E. Thesis, Anna University, Madras, 1994.

5. Tamil Selvi, Vermicomposting of municipal waste with coirpith and pongamea leaf litter, M. Sc. Dissertation, Bharathidasan University, Tiruchirappalli, 1996.

6. Ravichandran C, Chandrasekaran G E and Christy Priyadharsini F, Indian J Environ Prot., 2001, 21, 538-542. 


\section{A. AMSATH et al.}

7. Umamaheswari S and Vijayalaksmi G S, Poll Res., 2003, 22 339-341.

8. Umamaheswari S, J. Ecotoxicol. Environ Monit., 2005, 15, 69-72.

9. Trivedy R K and Goel P K, Chemical and biological methods for water pollution studies. Environ. Pub. Karad, India, 1986, 99.

10. Tandon H L S, Methods of analysis of soils, plants and waters. New Delhi, India, 1993.

11. Cohen S and Lewis H B, Fed Proc., 1949, 9, 191.

12. Lee E K, Earthworms. Academic Press, London, 1985.

13. Esther Rani D V, Perumalsamy K and Isaiarasu L, J Ecotoxicol Environ Monit., 2007, 17(1), 37-41.

14. Gunathilagaraj K and Ravignanam T, Madras, Agric. J, 1996, 83, 455-457.

15. Gaur A C, A Manual of Rural Composting FAO/UNDP, Regional Project RAS/75/004. Field Document No.15. FAO, Home, 1982, 102.

16 Lakshmi Bai L, and Vijayalakshmi, G S, Poll Res., 2000, 19,481-483.

17. Muthukumaravel K, Vermicomposting of Solid Wastes, M. Sc., Dissertation, Bharathidasan University, Tiruchirappalli, 1996.

18. Vasanthy M, Thamaraiselvi C and Ramadoss, A, J Ecotoxicol Environ Monit, 2005, 15, 207-211. 


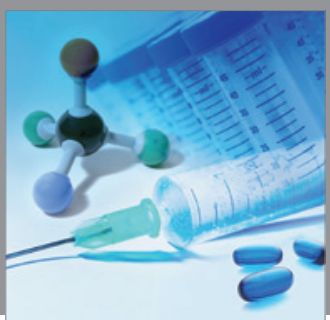

International Journal of

Medicinal Chemistry

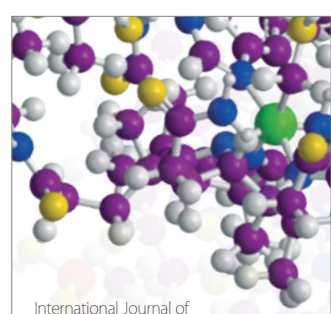

Carbohydrate Chemistry

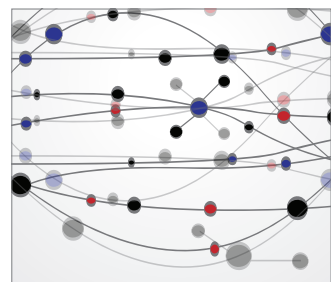

The Scientific World Journal
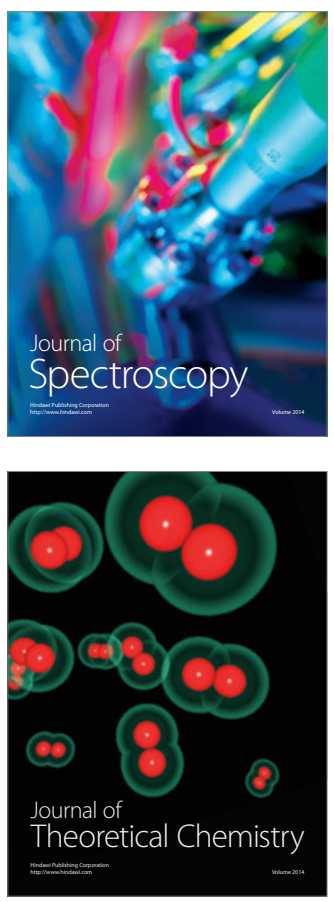
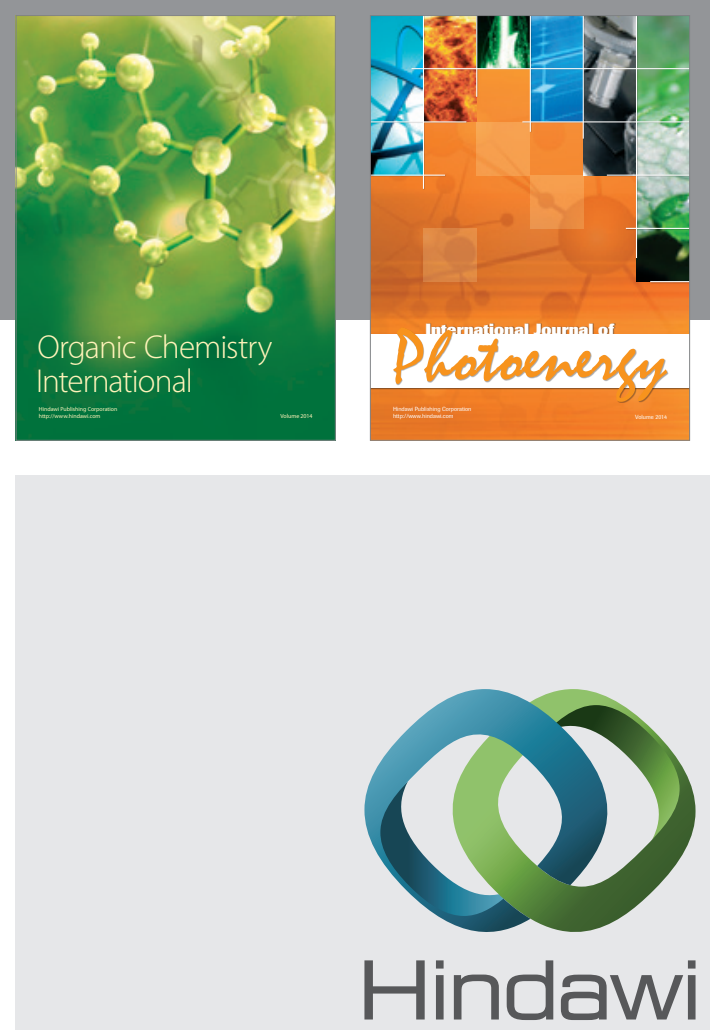

Submit your manuscripts at

http://www.hindawi.com
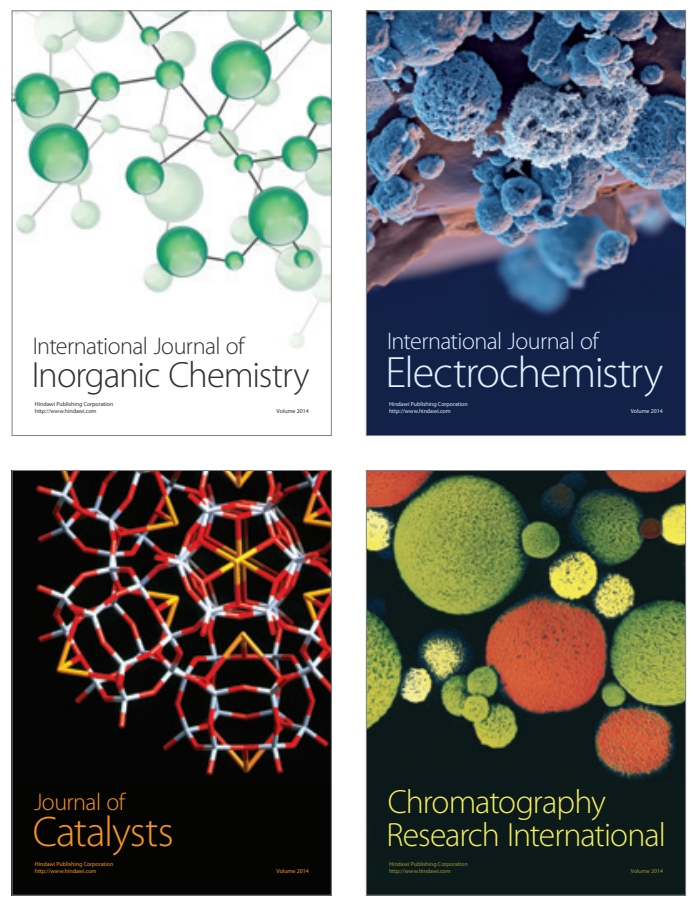
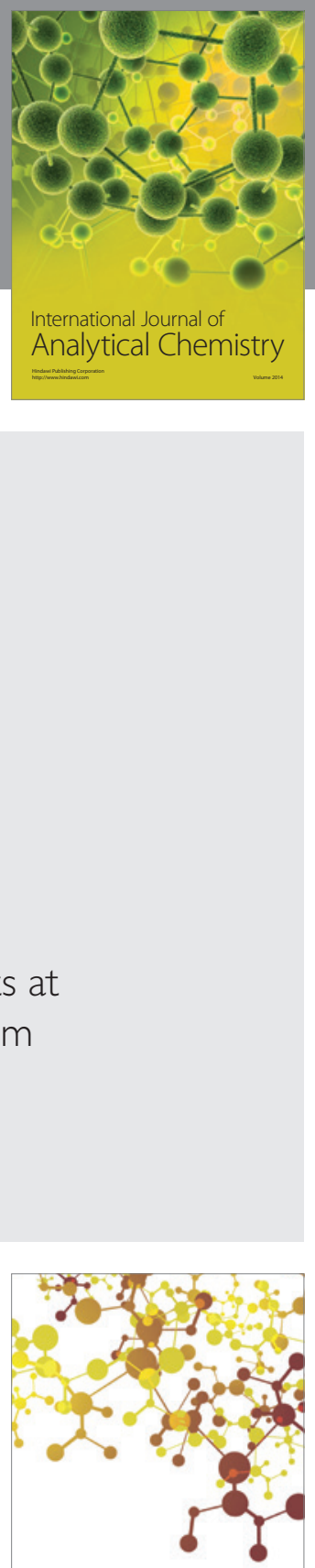

Journal of

Applied Chemistry
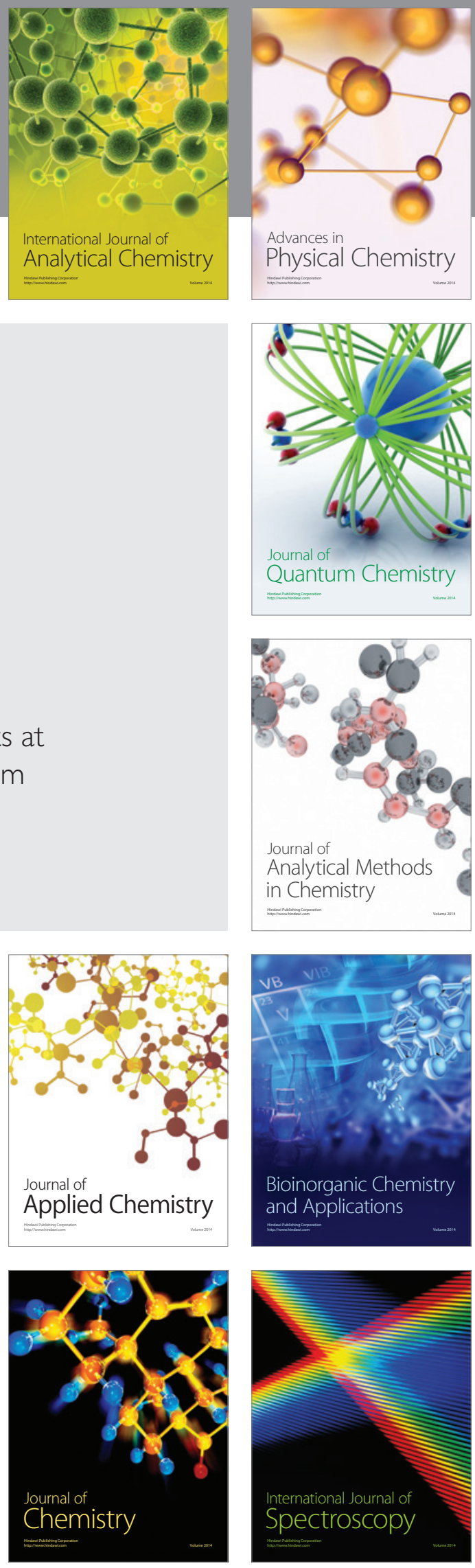